\title{
The Arab Maghreb Union: the "cost of non Maghreb" and sectoral prospects
}

\author{
Adnen OUESLATI, Riadh BRINI
}

$\mathrm{PhD}$ in Economics, Business and Economics University of Tunis

\section{Email address:}

wesadnen@yahoo.fr(A. OUESLATI),riadh_brini@yahoo.fr(R. BRINI)

\section{To cite this article:}

Adnen OUESLATI, Riadh BRINI. The Arab Maghreb Union: the "Cost of Non Maghreb" and Sectoral Prospects. International Journal of Economics, Finance and Management Sciences. Vol. 1, No. 6, 2013, pp. 285-291. doi: 10.11648/j.ijefm.20130106.14

\begin{abstract}
The aim of the paper is to find out the "No Maghreb" cost as untapped opportunities of intra regional trade and to check the existence of comparative advantages in the Maghreb region. We use panel data with gravity model to study the relationship between total exports and factors affecting them, as well as, the exports by sector and their determinants for a sample of 57 countries, between, 1980-2007. The goal is to point out the total exports potential as a proxy of the "No Maghreb" cost. The study also allows establishing whether there are comparative advantages among the region countries. The results show the weak level of intra regional trade comparing to its potential. They also demonstrate that Maghreb countries have similarities and disparities according to some comparative advantages. This contributes to encourage intra regional trade and improve trade perspectives in Maghreb.
\end{abstract}

Keywords: Trade Integration, No Cost Maghreb, Comparative Advantage, Potential Commercial Model Gravity

\section{Introduction}

Regional integration has become an economic necessity, given the intense competition that engages regional blocs. Due to its role in growth and the increased trade between the countries of the region, the Maghreb integration could be a factor in support for more efficient integration of Maghreb countries to the global economy. Even if integration is still quite low in the Maghreb, countries have tried to implement regional integration mechanisms to accelerate economic development over the past twenty years

An Intra Maghreb exchange does not exceed 3\% of the total trade of each country. It is an extremely low percentage compared to that made by regional groupings of similar level of development (EU, ALINA, ASEAN, etc.)

Given the importance of that suggested integration and the inescapable necessity for a closer economic partnership between the countries of the region, it would be useful to identify the contours of the Maghreb integration. To do so, we can assess the potential of exchange that may arise from the fulfillment of the Maghreb project.

This work allows us to deduce partially the comparative advantages of different countries in the region, and subsequently, the possibilities of intra-regional trade.

In this paper, a gravity model is estimated to calculate in a first step, the potential level of trade relative to its current level given the economic, geographical, historical and cultural of countries in the region. The potential difference between the calculated and the observed level is the "cost of non-Maghreb". In a second step, by calculating the trade potential by sector, we deduced the comparative advantages of different countries in the region, and therefore the prospects for intra-regional trade.

This article is organized as follows. In the next section we conduct a literature review on the potential trade of Arab countries. The third section presents the theoretical basis of the gravity model. In the fourth section we present our model, the variables and the data sources. The last section is devoted to present and analyze the results for the econometric estimates and the results of the calculation of the potential total trade sector.

\section{Review of Literature}

The gravity model has been used in the literature to assess the integration of the CEECs to the EU. The conclusions and recommendations made by the authors, especially Fontagné et al (2002), are quite mixed and depend on the period of the specification of the model used and the econometric methods used in the calculation of trade potential. 
The gravity model has been used extensively to calculate the potential of bilateral trade between Arab countries and the Maghreb countries. The main studies that have focused on the calculation of the potential trade between Arab countries and between Maghreb countries using this model are:

The study by Al-Athrash and Youssef (1999) and published by the IMF is among the first attempts interested to determine the potential of trade between Arab countries. The authors apply the Tobit estimation method for bilateral trade between 18 MENA countries and 43 other countries using aggregate data for the entire period 1995-1997. They show that intra Arabs are observed below the level calculated by the model.

Miniesy et al (2004) show, using a gravity model, the intra MENA and MENA countries trade with non-MENA is lower than the level predicted by the model.

Achy (2007) focuses only on countries of North Africa. He applies a gravity model increased by several cultural and institutional variables. He shows that the observed intra-regional trade is far below its potential.

World Bank (2006) shows, using panel data from a sample of 170 countries over the period 1980-2004, that the potential for intra-regional trade of goods in Maghreb is limited.

\section{Presentation of the Model}

The model used for each sector and for total trade in the context of this work takes the following general form:

$$
\begin{aligned}
& \ln X_{i j t}=\alpha_{0}+\alpha_{1} \ln Y_{i, t}+\alpha_{2} \ln Y_{j, t}+\alpha_{3} \ln y_{i, t}+\alpha_{4} \ln y_{j, t} \\
& +\alpha_{5} \ln D_{i, j}+\alpha_{6} H_{i, j}+\sum_{z} \alpha_{z} Z_{z, i, j}+\varepsilon_{i j t}
\end{aligned}
$$

Where;

$X_{i j t}$ : Exports from $\mathrm{i}$ to $\mathrm{j}$ in year $\mathrm{t}$

$y_{i t}$ : GDP per capita of the exporting country at time $t$,

$y_{j t}$ : GDP per capita of the exporting country at time $\mathrm{t}$.

$Y_{i t}$ : GDP of the exporting country at time t,

$Y_{j t}$ : Importing country's GDP at time t,

$D_{i j}$ : Distance between the capitals of the exporting and importing countries.

$Z$ :Is a vector of dummy variables capturing preferential trade agreements (unilateral preferential access, free trade agreement, common market ...).

$\mathrm{H}$ : Is a binary variable that captures the sharing of a common language and historical ties.

Our model takes this form:

$$
\begin{aligned}
& \ln X_{i j t}=\alpha_{0}+\alpha_{1} \ln P I B_{i, t}+\alpha_{2} \ln P I B_{j, t}+\alpha_{3} \ln P I B / T_{i, t}+\alpha_{4} \ln P I B / T_{j, t}+ \\
& \alpha_{5} \ln \text { Distcap }_{i, j}+\alpha_{6} F C_{i j}+\alpha_{7} \text { Langcom }_{i, j}+\alpha_{8} \text { Passcol }_{i, j}+\alpha_{9} U M A_{i, j, t}+\varepsilon_{i j t}
\end{aligned}
$$

Our objective is to calculate and analyze the potential total exports between Maghreb countries. We selected 57 countries, including the five Maghreb countries (Morocco, Algeria, Tunisia, Mauritania and Libya). We maintain the same sample except Mauritania to calculate the export potential by sector. Data export sector are not available for this country.

\subsection{Model and Calculation of Trade Potential}

\subsubsection{Methodology and Estimation Result}

We will conduct an empirical validation of the relationship between total exports of country $i$ to country $j$ and the different variables to explain that we have presented. Our analysis in this model is characterized by the following 57 countries over the period 1980-2007.

The estimation of our static panel depends, first, of the homogeneity test that detects the presence or absence of individual effects. We seek to test whether the individual effects $\eta_{i}$ are zero or not, we test the following hypothesis:

$$
\begin{aligned}
& \mathrm{H}_{0}: \eta_{i}=0 \\
& \mathrm{H}_{1}: \eta_{i} \neq 0
\end{aligned}
$$

The second step is to explain whether these individual effects are fixed and hence the estimation is carried out by techniques "within" or "between". If these are random effects, the estimation will be carried out by the method of Generalized Least Squares that gives the best linear unbiased estimator. We use the Hausman test (1978) estimates to see what we need to retain as method.

However, According to Kpodar (2007) when the model contains one or more invariant explanatory variables in the time we want to estimate their marginal impacts, we use the random effects model. We therefore conclude that our model is a random effects model, whose estimation is carried out by the Generalized Least Squares is the best linear unbiased estimator. The Lagrange multiplier test

\begin{tabular}{|c|c|}
\hline Variables & Coefficients \\
\hline $\ln \mathrm{PIB}_{\mathrm{it}}$ & $1,140 * * *(63,50)$ \\
\hline $\ln \mathrm{PIB}_{\mathrm{jt}}$ & $0,977 * * *(54,32)$ \\
\hline $\ln P I B / T_{i t}$ & $0,519^{* * *}(21,16)$ \\
\hline $\ln P I B / T_{j t}$ & $0,449 * * *(18,38)$ \\
\hline $\operatorname{lndistcap} \mathrm{i}_{\mathrm{i}, \mathrm{j}}$ & $-0,920 * * * \quad(-24,90)$ \\
\hline $\mathrm{FC}_{\mathrm{ij}}$ & $0,421 * *(2,32)$ \\
\hline Passcol $_{i, j}$ & $0,874 * * *(4,26)$ \\
\hline Langcom & $0,912 * * *(8,51)$ \\
\hline $\mathrm{UMA}_{\mathrm{i}, \mathrm{j}, \mathrm{t}}$ & $0,525 * * *(8,15)$ \\
\hline Constant & $-52,828 * * *(-13,17)$ \\
\hline Observations & 73928 \\
\hline homogeneity test & 65,84 \\
\hline Breush et Pagan test & $4.2 \mathrm{e}+05$ \\
\hline
\end{tabular}
suggested by Breush and Pagan (1979) allows us to test the significance of random effects. The following table summarizes the results of the estimation and the various tests that have allowed us to retain this method:

Table 1. Results of GLS estimates 
According to the table above, all the estimated variables are statistically significant. The elasticity associated with GDPi is positive and statistically significant, its value is 1.140. It states that, all other things being equal, an increase in GDP of $1 \%$ results in an increase in exports from $i$ to $j$ of $1.14 \%$.

The positive and statistically significant coefficient associated with the variable FC or "border" indicates that countries that share a common border tend to share about 1.5 more compared to countries that have no common border.

Similarly, the coefficients associated with variables "Langcom" and "Passcol" indicate that for countries that share a common language and a common colonial past tend to exchange approximately 2.4 and 2.5 times higher, respectively, compared to countries that have no common language or a common colonial past.

The coefficient associated with the variable "distcap" is negative and statistically significant. This variable is a proxy of transport costs, it indicates that bilateral trade decreases almost proportionally $(-0.92)$ compared to the distance, which confirms the theory.

In order to test the specificity of the Maghreb region compared to other countries in the world in terms of bilateral exports, we have introduced the variable "UMA" which refers to intra Maghreb. This variable takes the value 1 if both countries $\mathrm{i}$ and $\mathrm{j}$ partners are members of the Union of the Arab Maghreb, 0 otherwise.

The coefficient on this variable indicates that the bilateral exports between two countries $i$ and $j$ members of the AMU is 1.7 more than the bilateral exports between two countries $i$ and $j$ that are not members of the AMU. This result is somewhat surprising from what we have said, AMU still stalled and trade between the countries of the region does not exceed $3 \%$ of total trade. But during recent years and the economic embargo on Libya, trade between the countries of the region, particularly with Libya has grown considerably, which explains this result.

\subsubsection{Method and Results of Calculation of Trade Potential}

Table 2. Calculation of the potential for trade in millions U.S. \$ in 2007

\begin{tabular}{|c|c|c|c|c|c|}
\hline & Algeria & Libya & Morocco & Mauritania & Tunisia \\
\hline \multicolumn{6}{|l|}{ Observed exports } \\
\hline Total & $\underline{51354,82}$ & $\underline{44201,72}$ & $\underline{14500,88}$ & $\underline{54,36}$ & $\underline{9353,44}$ \\
\hline Exports to the UMA & 964,77 & 731,16 & 186,70 & 0,38 & 1112,84 \\
\hline share of AMU (1) & 1,878 & 1,65 & 1,28 & 0,70 & 11,89 \\
\hline \multicolumn{6}{|l|}{ Simulated exports } \\
\hline Total & $\underline{40769,18}$ & 12944,93 & $\underline{10882,47}$ & $\underline{119,76}$ & 14055,44 \\
\hline Exports to the UMA & 5076,80 & 1206,90 & 1515,76 & 6,35 & 1920,78 \\
\hline share of AMU (2) & 12,45 & 9,32 & 13,92 & 5,30 & 13,66 \\
\hline $\begin{array}{l}\text { Creation potential of trade in the } \\
\text { Maghreb region }\end{array}$ & $\underline{4112,03}$ & $\underline{475,74}$ & $\underline{1329,06}$ & $\underline{5,96}$ & $\underline{807,94}$ \\
\hline $\begin{array}{l}\text { Share of the potential in the Observed } \\
\text { total trade }(\%)\end{array}$ & 8,007 & 1,07 & 9,165 & 10,97 & 8,63 \\
\hline$(2) /(1)$ & 6,62 & 5,63 & 10,81 & 7,53 & 1,14 \\
\hline
\end{tabular}

The analysis of trade flows taking place between two or more countries is often achieved using a gravity model based on panel data. To account for the heterogeneity of export flows we estimate the gravity model from panel data.

Our method estimates a gravity model linking the exports of country $i$ to country $j$ at another of its determinants. Relationships statistics from panel regressions show the impact "natural" or "type" determinants of trade on bilateral trade flows and we hypothesized that these effects would apply to the average country in the Maghreb region in order to calculate the potential of intra Maghreb.

According to Fontagné et al (2002) and despite the criticism to his work (Hummels and Levinsohn (1995) and Evenett and Keller (1998)), the gravity model is an invaluable tool for calculating the potential of bilateral trade. This potential is defined as the fraction of the "normal" trade determined by macroeconomic conditions in the countries of the sample.

Our approach consists of estimating an equation of bilateral trade based on the gravity model of trade for country reference sample and use this time in a second simulation equation for the Maghreb countries to calculate the potential of intra-regional trade. The potential of trade is the difference between simulated exchange and observed trade (Fontagné et al 2002). When trading volume is observed above the forecast model, the trade gap between the two countries is considered as positive, and when the trading volume is observed below the model prediction, the trade gap between the two countries is considered as negative.

We apply this method to calculate, in a first step, the potential total trade within the Maghreb and then to calculate the potential of intra-Maghreb trade by sector.

\subsubsection{The "Cost of Non-Maghreb"}

The calculation results of simulated exports of various Maghreb countries on the basis of the estimation of the gravity model and according to Fontagné et al (2002) for the year 2007 are presented in the following table: 
The first observation that emerges from the reading of this table is that the simulated exports from Algeria and Libya are lower exports observed. This is explained by the fact that these countries are major producers and exporters of oil. In contrast, the simulated exports of Tunisia and Mauritania exceed exports observed. Finally, Moroccan exports observed in 2007 are higher than those simulated. Moroccan exports have experienced a considerable increase during this period. According to the official website of the National Foreign Trade Council (NCCC), Moroccan exports in 2006 were driven by a worldwide business very dynamic which crystallized in high demand addressed to Morocco. The good performance of 2006 is mainly due to the recovery of quotas on Chinese imports to the EU. A respite runs again until 2007.

The second observation is that the share of intraMaghreb observed is very small compared to its share in exports simulated. The share of Algerian exports to all Maghreb countries, for example, does not exceed $2 \%$ of its total exports observed. In particular, the share of Tunisian exports to the Maghreb region, in 2007, is relatively high exceeding $11 \%$.

Then, the ratio (2) / (1) whose values are obtained by comparing the different countries of the region from the AMU in simulated exports to its share in exports observed shows that the share of exports simulated the AMU is very high and about 11 times, for example, Morocco and Algeria for 7 times. The amount of Algerian exports to the Maghreb countries would be five billion or about $13 \%$ of total exports observed in Algeria. The same applies to Morocco, whose total exports to the Maghreb countries should have a little more than $\$ 1.5$ billion or about $14 \%$ of total exports observed. The same goes for the other Maghreb countries.

Finally, the trade creation potential in the Maghreb region defined by Fontagné et al (2002) as the difference between exports and exports simulated observed is very high for the countries of the region. In particular, it exceeds 4.1 billion dollars for the case of Algeria, 1300 million dollars in the case of Morocco and 800 million dollars in the case of Tunisia. Creation of potential exchange is very high for all countries of the region; hence the "cost of nonMaghreb" in terms of untapped potential of intra-regional trade is very high.

\subsubsection{Prospects of Commercial Sector}

The calculation of potential exports by sector of Maghreb countries allows us to reformulate another idea on the trade potential of these countries by comparing the current structure of exports sector structure simulated or natural. This work allows us to deduce partially the comparative advantages of different countries in the region. The method of estimation of the gravity model by sector is the same as that used in the estimation of the gravity model for exports. We kept the same variables and the same sample of countries except Mauritania whose data by sector are unavailable. We chose ten sectors.

We estimate a gravity model for each sector. The gravity equation by sector connects the exports by sector of country $i$ to country $j$ with the same variables and building variables used to estimate friction model for total exports. The results are summarized in the following table:

Table 3. Results of estimates Sectors

\begin{tabular}{|c|c|c|c|c|c|c|c|c|c|c|}
\hline \multicolumn{11}{|c|}{ Coefficients by sector } \\
\hline Variables & S1 & S2 & S3 & S4 & S5 & S6 & S7 & S8 & S9 & $\mathbf{S 1 0}$ \\
\hline $\ln \mathrm{PIB} / \mathrm{T}_{\mathrm{it}}$ & $\begin{array}{l}0,46 * * * \\
(14,06)\end{array}$ & $\begin{array}{l}0,54 * * * \\
(15,45)\end{array}$ & $0,03 \quad(1,04)$ & $\begin{array}{l}0,70 * * * \\
(22,14)\end{array}$ & $\begin{array}{l}1,01 * * * \\
(31,32)\end{array}$ & $\begin{array}{l}0,78 * * * \\
(27,81)\end{array}$ & $\begin{array}{l}-0,07 * *(- \\
2,08)\end{array}$ & $\begin{array}{l}0,22 * * * \\
(4,57)\end{array}$ & $\begin{array}{l}-0,34 * * * \\
(-10,69)\end{array}$ & $\begin{array}{l}0,37 * * * \\
(11,49)\end{array}$ \\
\hline $\ln P I B / T_{j t}$ & $\begin{array}{l}0,77 * * * \\
(23,30)\end{array}$ & $\begin{array}{l}0,52 * * * \\
(14,85)\end{array}$ & $\begin{array}{l}0,68 * * * \\
(20,50)\end{array}$ & $\begin{array}{l}0,64 * * * \\
(20,12)\end{array}$ & $\begin{array}{l}0,77 * * * \\
(24,22)\end{array}$ & $\begin{array}{l}0,26 * * * \\
(9,50)\end{array}$ & $\begin{array}{l}0,72 * * * \\
(19,25)\end{array}$ & $\begin{array}{l}0,56 * * * \\
(11,43)\end{array}$ & $\begin{array}{l}0,45 * * * \\
(14,06)\end{array}$ & $\begin{array}{l}0,77 * * * \\
(23,84)\end{array}$ \\
\hline $\ln \mathrm{PIB}_{\text {it }}$ & $\begin{array}{l}1,29 * * * \\
(53,50)\end{array}$ & $\begin{array}{l}0,88 * * * \\
(34,75)\end{array}$ & $\begin{array}{l}1,29 * * * \\
(52,41)\end{array}$ & $\begin{array}{l}1,26 * * * \\
(53,14)\end{array}$ & $\begin{array}{l}1,58 * * * \\
(66,50)\end{array}$ & $\begin{array}{l}1,40 * * * \\
(67,61)\end{array}$ & $\begin{array}{l}0,60 * * * \\
(22,01)\end{array}$ & $\begin{array}{l}0,90 * * * \\
(25,24)\end{array}$ & $\begin{array}{l}0,64 * * * \\
(26,96)\end{array}$ & $\begin{array}{l}0,84 * * * \\
(35,20)\end{array}$ \\
\hline $\ln \mathrm{PIB}_{\mathrm{jt}}$ & $\begin{array}{l}0,59 * * * \\
(24,86)\end{array}$ & $\begin{array}{l}0,71 * * * \\
(28,22)\end{array}$ & $\begin{array}{l}0,79 * * * \\
(32,23)\end{array}$ & $\begin{array}{l}0,78 * * * \\
(32,84)\end{array}$ & $\begin{array}{l}0,87 * * * \\
(36,57)\end{array}$ & $\begin{array}{l}0,92 * * * \\
(44,51)\end{array}$ & $\begin{array}{l}1,01 * * * \\
(37,18)\end{array}$ & $\begin{array}{l}0,94 * * * \\
(26,76)\end{array}$ & $\begin{array}{l}0,83 * * * \\
(34,80)\end{array}$ & $\begin{array}{l}0,77 * * * \\
(32,59)\end{array}$ \\
\hline $\mathrm{FC}_{\mathrm{ij}}$ & $\begin{array}{l}0,94 * * * \\
(4,12)\end{array}$ & $\begin{array}{l}1,09 * * * \\
(4,59)\end{array}$ & $0,04 \quad(0,17)$ & $\begin{array}{l}0,63 * * * \\
(2,61)\end{array}$ & $\begin{array}{l}0,36 \\
(1,51)\end{array}$ & $\begin{array}{l}0,74 * * * \\
(3,63)\end{array}$ & $\begin{array}{l}1,22 * * * \\
(5,06)\end{array}$ & $\begin{array}{l}1,25 * * * \\
(3,96)\end{array}$ & $\begin{array}{l}0,78 * * * \\
(3,32)\end{array}$ & $\begin{array}{l}0,92 * * * \\
(3,93)\end{array}$ \\
\hline Passcol $_{i, j}$ & $0,541 *(1,76)$ & $\begin{array}{l}0,24 \\
(0,82)\end{array}$ & $0,35 \quad(1,05)$ & $\begin{array}{l}0,64 * * \\
(2,33)\end{array}$ & $\begin{array}{l}1,07 * * * \\
(3,89)\end{array}$ & $\begin{array}{l}0,44^{*} \\
(1,74)\end{array}$ & $\begin{array}{l}-0,11 \\
0,37)\end{array}$ & $\begin{array}{l}0,91 * * \\
(2,24)\end{array}$ & $\begin{array}{l}0,21 \\
(0,73)\end{array}$ & $\begin{array}{l}0,42 \\
(1,39)\end{array}$ \\
\hline lndistcap $_{\mathrm{i}, \mathrm{j}}$ & $\begin{array}{l}-1,28 * * * \\
(-27,02)\end{array}$ & $\begin{array}{l}-1,09 * * * \\
(-22,17)\end{array}$ & $\begin{array}{l}-1,29 * * * \\
(-25,53)\end{array}$ & $\begin{array}{l}-1,13 * * *(- \\
23,18)\end{array}$ & $\begin{array}{l}-1,07 * * * \\
(-21,80)\end{array}$ & $\begin{array}{l}-1,12 * * *(- \\
26,93)\end{array}$ & $\begin{array}{l}-1,01 * * *(- \\
18,96)\end{array}$ & $\begin{array}{l}-1,1 * * * \\
(-21,3)\end{array}$ & $\begin{array}{l}-0,96 * * * \\
(-20,1)\end{array}$ & $\begin{array}{l}-0,87 * * *(- \\
18,32)\end{array}$ \\
\hline $\mathrm{UMA}_{\mathrm{i}, \mathrm{j}, \mathrm{t}}$ & $\begin{array}{l}0,59 * * \\
(0,269)\end{array}$ & $\begin{array}{l}0,75 * * \\
(2,27)\end{array}$ & $0,08 \quad(0,36)$ & $\begin{array}{l}0,33 \\
(1,41)\end{array}$ & $\begin{array}{l}-0,35 \\
1,43)\end{array} \quad \quad \quad$ & $\begin{array}{l}0,73 * * * \\
(3,24)\end{array}$ & $\begin{array}{l}-1,35 * * *(- \\
3,78)\end{array}$ & $\begin{array}{l}-0,13 \\
(-0,28)\end{array}$ & $\begin{array}{l}-0,87 * * * \\
(-3,60)\end{array}$ & $\begin{array}{l}0,20 \\
(0,73)\end{array}$ \\
\hline Langcom & $\begin{array}{l}0,84 * * * \\
(6,29)\end{array}$ & $\begin{array}{l}0,73 * * * \\
(5,24)\end{array}$ & $\begin{array}{l}0,93 * * * \\
(6,40)\end{array}$ & $\begin{array}{l}1,15 * * * \\
(8,13)\end{array}$ & $\begin{array}{l}0,93 * * * \\
(6,53)\end{array}$ & $\begin{array}{l}0,86 * * * \\
(7,09)\end{array}$ & $\begin{array}{l}0,96 * * * \\
(6,42)\end{array}$ & $\begin{array}{l}1,58 * * * \\
(8,36)\end{array}$ & $\begin{array}{l}0,96 * * * \\
(6,99)\end{array}$ & $\begin{array}{l}1,146^{* * *} \\
(8,27)\end{array}$ \\
\hline Constant & $\begin{array}{l}-51,91 * * * \\
(-81,70)\end{array}$ & $\begin{array}{l}-42,46^{* * *} \\
(-62,19)\end{array}$ & $\begin{array}{l}-50,16 * * *(- \\
79,00)\end{array}$ & $\begin{array}{l}-56,51 * * * \\
(-92,82)\end{array}$ & $\begin{array}{l}-70,05 * * * \\
(-114,76)\end{array}$ & $\begin{array}{l}-60,45 * * * \\
(-111,39)\end{array}$ & $\begin{array}{l}-41,42 * * * \\
(-57,03)\end{array}$ & $\begin{array}{l}-44,6 * * * \\
(-46,08)\end{array}$ & $\begin{array}{l}-31,2 * * * \\
(-50,76)\end{array}$ & $\begin{array}{l}-45,33 * * * \\
(-72,71)\end{array}$ \\
\hline
\end{tabular}


Estimating equations by sector allows us to calculate the potential total exports by sector. Our goal is to determine the existence of a comparative advantage. The difference between simulated and observed indicates the existence of a comparative advantage. The results of our calculations are presented in the following table:

Table 4. Structure of exports from Maghreb countries.

\begin{tabular}{|c|c|c|c|c|c|c|c|c|c|}
\hline \multirow[b]{2}{*}{ Sectors } & & \multicolumn{2}{|l|}{ Tunisia } & \multicolumn{2}{|l|}{ Algeria } & \multicolumn{2}{|l|}{ Morocco } & \multicolumn{2}{|l|}{ Libya } \\
\hline & & Simulated & Observed & Simulated & Observed & Simulated & Observed & Simulated & Observed \\
\hline \multirow{2}{*}{ S1 } & Total & 1,5 & 1,3 & 1,5 & 0,0 & 1,3 & 0,2 & 1,2 & 0,0 \\
\hline & Total Maghreb & 3,0 & 11,5 & 3,9 & 0,1 & 3,0 & 1,0 & 2,7 & 0,0 \\
\hline \multirow{2}{*}{ S2 } & Total & 10,9 & 1,6 & 6,5 & 0,5 & 7,8 & 2,1 & 10,8 & 0,8 \\
\hline & Total Maghreb & 18,2 & 5,4 & 12,2 & 11,2 & 14,3 & 17,5 & 24,1 & 4,1 \\
\hline \multirow{2}{*}{ S3 } & Total & 7,8 & 33,0 & 9,1 & 0,0 & 11,4 & 30,7 & 5,5 & 0,0 \\
\hline & Total Maghreb & $\underline{3,3}$ & $\underline{2,2}$ & 3,0 & 0,3 & $\underline{4,9}$ & $\underline{4,9}$ & 2,9 & 0,0 \\
\hline \multirow{2}{*}{ S4 } & Total & 5,8 & 3,0 & 6,8 & 0,0 & 0,0 & 1,6 & 6,6 & 0,0 \\
\hline & Total Maghreb & 6,4 & 8,0 & 8,0 & 0,3 & 0,0 & 11,5 & 6,6 & 0,2 \\
\hline \multirow{2}{*}{ S5 } & Total & 20,3 & 26,2 & 35,6 & 0,1 & 19,8 & 20,5 & 32,2 & 0,0 \\
\hline & Total Maghreb & 10,6 & 25,6 & 20,2 & 0,4 & 13,2 & 10,5 & 10,3 & 0,2 \\
\hline \multirow{2}{*}{ S6 } & Total & 13,4 & 7,8 & 15,8 & 0,7 & 11,5 & 11,0 & 16,7 & 1,6 \\
\hline & Total Maghreb & 21,2 & 18,2 & 28,4 & 4,5 & 23,3 & 20,8 & 29,2 & 8,8 \\
\hline \multirow{2}{*}{ S7 } & Total & 5,1 & 1,5 & 2,7 & 0,6 & 6,3 & 7,5 & 3,3 & 0,1 \\
\hline & Total Maghreb & 0,9 & 0,6 & 0,3 & 0,0 & 0,9 & 5,6 & 0,6 & 1,2 \\
\hline \multirow{2}{*}{ S8 } & Total & 10,2 & 16,8 & 6,8 & 97,9 & 9,4 & 2,6 & 5,6 & 97,4 \\
\hline & Total Maghreb & 24,5 & 0,8 & 17,3 & 82,3 & 26,7 & 3,8 & 12,3 & 85,0 \\
\hline \multirow{2}{*}{ S9 } & Total & 14,8 & 1,6 & 8,0 & 0,1 & 21,8 & 13,0 & 8,2 & 0,0 \\
\hline & Total Maghreb & 4,8 & 4,0 & 2,3 & 0,3 & 6,8 & 0,7 & 3,3 & 0,1 \\
\hline \multirow{4}{*}{ S10 } & Total & 10,2 & 7,1 & 7,2 & 0,1 & 10,8 & 10,8 & 9,8 & 0,0 \\
\hline & Total Maghreb & 7,2 & 23,8 & 4,5 & 0,6 & 6,8 & 23,7 & 8,1 & 0,4 \\
\hline & Total Sect & 100 & 100 & 100 & 100 & 100 & 100 & 100 & 100 \\
\hline & Total sect UMA & 100 & 100 & 100 & 100 & 100 & 100 & 100 & 100 \\
\hline
\end{tabular}

This table summarizes the results of our calculations. For each Maghreb countries we calculated in the first column structure simulated sectoral exports to the world and to the North African market. This column was obtained in several steps, we first calculated the potential simulated for each sector and for each of the 56 countries in the sample and then we summed by sector over 56 countries and on four Maghreb partners exchange, we calculated the sectoral structure simulated by the rest of the world (the 56 countries in the sample) and compared to the Maghreb countries. The sectoral structure observed in the second column for each country, was obtained by summing the area of the 56 countries and on four Maghreb countries to the exchange partners.
The differences between the structure of exports partly reflect simulated and observed (since the model does not include variables by sector) comparative advantages compared to the rest of the world and, in particular, in relation to the Maghreb countries. From this table we see that:

\section{Case 1: Tunisia}

The first observation that emerges from the reading of this table is that Tunisia is specialized or has a comparative advantage in Textiles (S3), Power Mechanics (S5) and Energy (S8), but the share of exports in these sectors to the countries of the region remains low, except exports of mechanical and electrical sector (S5). In contrast, the share 
of exports of Construction Materials sector (S1) and Food (S10) are high even if Tunisia does not have a comparative advantage in these sectors globally.

\section{Case 2: Algeria}

Algeria, after reading table, specializes in the Energy sector (S8), it is a major oil producer. But it should be noted that the share of exports in this sector to the Maghreb market exceeds $80 \%$ of its total exports and even exceeds the calculated potential.

\section{Case 3: Morocco}

Morocco is specialized in Textiles (S3), but the share of exports in this sector compared to its exports to the Maghreb has not exceeded its potential. In contrast, the share of exports of wood and paper (S4) and Food (S10) compared to its total exports to this market exceeded the potential.

\section{Case 4: Libya}

Libya is a major oil producer and Table 5 shows that it has a comparative advantage in the Energy sector (S8). As for the Algerian case the share of exports from this sector to the Maghreb market exceeds $80 \%$ of its total exports to the North African market and also exceeds the calculated potential. The following table summarizes the different results of our calculations sector.

\begin{tabular}{|c|c|c|c|c|c|}
\hline & & Tunisia & Morocco & Algeria & Libya \\
\hline \multirow{2}{*}{$\begin{array}{l}\text { Advantage } \\
\text { by sector }\end{array}$} & $\begin{array}{l}\text { Advantage } \\
\text { worldwide }\end{array}$ & $\begin{array}{l}\text { S3, S5, } \\
\text { S8 }\end{array}$ & S3 & S8 & S8 \\
\hline & $\begin{array}{l}\text { Advantage } \\
\text { in the } \\
\text { Maghreb }\end{array}$ & $\begin{array}{l}\text { S1, S4, } \\
\text { S5, S10 }\end{array}$ & $\begin{array}{l}\text { S2, S4, } \\
\text { S10 }\end{array}$ & S8 & S8 \\
\hline
\end{tabular}

We conclude that there is a similarity, but also a diversity of some comparative advantages depending on the product, and consequently, there is a certain complementarity, especially in the sector of energy between the different countries in the region which is a good factor for the prospects of intra Maghreb.

\section{Conclusion}

The main objective of this work is to examine the relative performance of trade in the Maghreb region. It was more precisely assess the extent of the "cost of nonMaghreb" is very high in terms of potential trade especially in terms of energy, despite efforts by terms of reducing tariff and non-tariff in the Maghreb region as a whole is lagging behind comparator countries when it comes to trade liberalization within Maghreb.

The results show that, firstly, intra Maghreb is very low compared to its potential. The total trade model highlights a large untapped market potential of the Maghreb market whose main cause and cost transfer rates. This untapped potential is the "cost of non-Maghreb" to the extent that a union can lower transfer costs and consequently a potential exploitation. Second, the results also show that the countries of the region have both similarity and diversity of certain comparative advantages that can stimulate intraregional trade.

The analysis in the context of this paper presents empirical results which suggest that the Maghreb countries could be an economic union crowned with success. The high potential untapped and the existence of a diversity of perspectives highlight comparative advantages of developing intra-regional trade.

Integration and regional cooperation can help to solve the Maghreb countries a number of problems, in particular, the small national markets, strengthening the bargaining power. But the question is how to provoke the revival of the Arab Maghreb Union?

\section{References}

[1] Achy L (2007). Le commerce intra-régional : l'Afrique du Nord est-elle une exception. L'Année du Maghreb [En ligne], III | 2007, mis en ligne le 01 novembre 2010. URL : http://anneemaghreb.revues.org/395

[2] Al-Atrash H, Youssef T., (1999), «Intra-Arab Trade : is it too little? » IMF Working Papers, WP/00/10.

[3] Anderson J., (1979), " A theoretical foundation for the gravity equation ", American Economic Review, 69, pp. 106-116.

[4] Banque Mondiale (2006), « Is the a new vision for Maghreb economic integrations? »volume I : Main Report, Social and economic Development group, Middle East and North Africa region, The World Bank

[5] Breusch.T.S., Pagan.A.R., (1979), «A Simple Test for Heteroscedasticity and Random Coefficient Variation», Econometrica 47, pp1287-1294

[6] Carey H.C., (1858), "Principles of Social Science ", Philadelphia, J. Lippincott

[7] Combes.P.F., thierry.M., Thisse.J.F., (2006), «Economie géographique: l'intégration des régions et des nations», Economica, Paris.

[8] Eventt S.J., Keller W. (2002) "On theories explaining the success of gravity equation" Journal of Political Économy, vol. 110 (2), pp. 281-316.

[9] Fontagné L, Pajot M, Pasteels J.M ., (2002), « Potentiels de commerce entre économies hétérogènes : un petit mode d'emploi des modèles de gravit » Économie et Prévision $n^{\circ}$ 152-153, pp 115 à 139.

[10] Hausman J., (1978), " Specification tests in econometrics», Econometrica $46 \quad$ (6), pp.1251-1271. http://129.3.20.41/eps/prog/papers/0501/0501107.pdf

[11] Hummels D., Levinsohn J., (1995), «Monopolistic competition and international trade: Reconsidering the Evidence», Quarterly Journal of Economics, vol. 110 (3), pp. 799-836. 
[12] Kpodar K., (2007), «Manuel d'initiation à Stata (Version 8) », Centre D'Etudes et de Recherches sur le Développement International.

[13] Miniesy R.S., Nugent J.B., et Yousef T.M., (2004), «Intraregional trade integration in the Middle East. Past Performance and Future Potential» in H. Hakimian et J.B. Nugent (eds). Trade Policy and Economic Integration in the Middle East and North Africa. Economic Boundaries in Flux, Routledge, London.
[14] Reilly W.J., (1931), « The law of retail gravitation », New York, Pilsbury.

[15] Tinbergen J., (1962), " Shaping the world economy: suggestions for an International Economic Policy», New York, Twentieth Century Fund. 